\title{
Effect of addition of sodium dehydroacetate on the fermentation of blue-grass silage ${ }^{*}$
}

\author{
Y.G. Zhang ${ }^{1}$, X.H. Zhang and X.L. Xie \\ College of Animal Sciences and Technology, Northeast Agricultural University \\ Harbin 150030, P.R. China
}

\begin{abstract}
The objective of this trial was to examine the effect of applying sodium dehydroacetate on the fermentation of blue-grass silage. Whole plant blue-grass was ensiled in laboratory bags after treated with sodium dehydroacetate at three rates, $0.05 \%$ of fresh weight (SD1), $0.1 \%$ of fresh weight (SD2), and $0.2 \%$ of fresh weight (SD3), LuproMix NC as a positive control ( $0.35 \%$ of fresh weight), or no additive (untreated). The each SD treatment had lower the final $\mathrm{pH}$ than the untreated $(\mathrm{P}<0.05)$, but the difference was not significant compared with positive control $(\mathrm{P}>0.05)$. All the three SD treatments had lower ammonia nitrogen (as \% total nitrogen) than the untreated $(\mathrm{P}<0.05)$, and the significant differences in ammonia nitrogen between SD3 treatment and LuproMix treatment were observed $(\mathrm{P}<0.05)$. Lactic acid bacteria count $(\mathrm{cfu} / \mathrm{g})$ after ensiling were unaffected by application rates of SD, but yeast/mold counts were lower for SD treatments than both controls. The SD3 treatment had the greatest the lactic acid concentration and ratio of lactic acid:acetic acid, while LuproMix had the lowest the lactic acid concentration and the ratio. Except for SD3, there were no differences in the lactic acid concentration among all the treatments. Thus, it is concluded that blue-grass silage quality can be improved by using SD3 as a antifungal additive to reduce the growth of detrimental bacteria.
\end{abstract}

KEY WORDS: blue-grass, sodium dehydroacetate, silage, fermentation

\section{INTRODUCTION}

Silages are often the prefered forage for dairy cattle in northeast China. They represent one of the lowest cost sources of energy and proteins as well as a good fibre source for maintaining rumen function and fat yield.

In practice, it is not easy to preserve nutritional value of silages due to storage losses. Besides an economic loss of nutrients, feeding spoiled silage to ruminants

\footnotetext{
* Supported by the Scientific Research Department, Heilongjiang Province Education Committee, P.R. China

${ }^{1}$ Corresponding author: e-mail: zhangyonggen@sina.com
} 
depresses dry matter intake and decreases production (Hoffman and Ocker, 1997; Whitlock et al., 2000). Up to date, many scientists have conducted studies using various chemical additives with antifungal properties in an attempt to reduce spoilage losses (Hingston and Christensen, 1982; Kung et al., 2000). However, some studies found that the use of chemical additives have not given consistently beneficial results, and some antifungal acids are corrosive and unsafe to handle. To overcome these problems, salts of acid have been developed and evaluated (Lingvall and Lattemae, 1999). The undissociated form of these salts pass through cell membrances of yeasts and molds and release their protons into the cytoplasm, thereby acidifying the intracellular region (Buxton et al., 2003).

However, these products appear to be costly because inadequate dose can not improve aerobic stablility of silage and so must restrict their application. For example, buffered propionic acid-based additive need applying at $0.3 \%$ of fresh forage weight to improve silage quality (Kung et al., 1998). Sodium dehydroacetate is a publicly recognized safety feed additive that is widely utilized in feed preservation in China. It is reported that sodium dehydroacetate can improve aerobic stability of maize or half-dried silage (Plegge, 1992).

The objective of this trial is to determine the effect of addition of sodium dehydroacetate on fermentation characteristics and further discuss the feasibility of using sodium dehydroacetate as a preservative of silages.

\section{MATERIAL AND METHODS}

\section{Design and treatments}

Whole-plant Canada blue-grass from one field was harvested at the soft dough stage of maturity (about $25 \% \mathrm{DM}$ ). In the trial, whole-plant forage was treated with 1 . no additive (Untreated, U), 2. sodium dehydroacetate (Acetate Chemical, Ltd.,Nantong, CN), $0.05 \%$ of fresh weight (SD1), 3. sodium dehydroacetate, $0.1 \%$ of fresh weight (SD2), 4 . sodium dehydroacetate, $0.2 \%$ of fresh weight (SD3), or 5. LuproMix NC as a positive control (BASF product with calcium propionate as main efficient ingredient), $0.35 \%$ of fresh weight (LM) and was ensiled in bags (35 kg each).

The experiment was a completely randomized design with ten duplicates each treatment. All chemical additives were mixed with water and sprayed onto the forage mass using a garden sprayer prior to bagging. In order to maintain consistent moisture of different treated silages, untreated silage was sprayed the same volume of water as treated silage. Bags were filled, sealed and stored at room temperature $\left(18^{\circ} \mathrm{C}\right)$. 


\section{Samplings and chemical analysis}

After $45 \mathrm{~d}$ of storage, samples were taken approximately $20 \mathrm{~cm}$ from the surface of the bag from three locations along the length of each bag and analysed for fermentation characteristics and nutrient composition. Water extracts were prepared on silage samples by adding $50 \mathrm{~g}$ of fresh silage to $150 \mathrm{ml}$ of deionized water and soaking overnight at $4^{\circ} \mathrm{C}$ in the refrigerator. After homogenizing for $1 \mathrm{~min}$, the $\mathrm{pH}$ of the water extract was measured and a portion of it was filtered through Whatman 54 filter paper and frozen before analysis for ammonia-N, lactic acid and acetic acid. Ammonia-N was measured by ammonia gas sensing electrode (ORION IonAnalyzer EA904, USA). Acetic, propionic and butyric acid concentrations were determined using a GC-2010 (Shimadzu, Japan). The lactic acid concentration was analysed by HPLC method (Waters 600E, USA). The remaining water extract was filtered through a double layers of cheesecloth and enumerated for lactic acid bacteria and yeast $/$ mold. The numbers of yeast $/ \mathrm{mold}$ were examined by using yeast/mold fast counting plate (RIDA Inc., Germany). Lactic acid bacteria was plated on MRS culture medium and then incubated in a $30^{\circ} \mathrm{C}$ oven for $3 \mathrm{~d}$. The numbers of bacteria colonies were expressed as the number of viable bacteria present in $1 \mathrm{~g}$ of silage inoculant $\left(\log _{10} \mathrm{cfu} / \mathrm{g}\right)$.

\section{Statistical analysis}

Chemical data were presented on a DM basis and data were analysed using the GLM procedure (SAS, 1998). The treatment means were compared using Student-Newman Keul's test when probabilities were less than 0.05 .

\section{RESULTS}

Fermentation products and numbers of organisms from silages are shown in Table 1. On day 45 of storage, the $\mathrm{pH}$ of $\mathrm{U}$ was the highest of all treatments $(\mathrm{P}<0.05)$. No significant difference in $\mathrm{pH}$ was observed among other treatments on day 45 of silage fermentation, the concentration of $\mathrm{NH}_{3} \mathrm{~N}$ (as \% of total $\mathrm{N}$ ) of $U$ was the highest of all treatments. Each SD treated silage had significantly lower ammonia- $\mathrm{N}$ concentration compared with $\mathrm{U}(\mathrm{P}<0.05)$. Moreover, difference in $\mathrm{NH}_{3} \mathrm{~N}$ content between SD3 treated silage and $\mathrm{U}$ attained statistically very significant level $(\mathrm{P}<0.01)$. The ammonia-N concentration did not differ among other treatments $(\mathrm{P}>0.05)$. In addition, $\mathrm{SD} 3$ treated silage had the lowest content of ammonia-N of all of the treatments. 
Table 1. Fermentation end products and numbers of organisms in blue-grass silage on $45 \mathrm{~d}$ of ensiling, \%DM basis or as stated

\begin{tabular}{lcccccc}
\hline \multirow{2}{*}{ Item } & \multicolumn{7}{c}{ Silage treatment1 } \\
\cline { 2 - 7 } & $\mathrm{U} 1$ & $\mathrm{SD} 1$ & $\mathrm{SD} 2$ & $\mathrm{SD} 3$ & $\mathrm{LM}$ & $\mathrm{SE}$ \\
\hline $\mathrm{pH}$ & $4.74^{\mathrm{a}}$ & $4.18^{\mathrm{b}}$ & $4.40^{\mathrm{ab}}$ & $4.12^{\mathrm{b}}$ & $4.24^{\mathrm{b}}$ & 0.01 \\
$\mathrm{NH} 3 \mathrm{~N}, \%$ total N & $10.4^{\mathrm{A}}$ & $8.5^{\mathrm{AB}}$ & $8.15^{\mathrm{AB}}$ & $5.80^{\mathrm{B}}$ & $7.88^{\mathrm{AB}}$ & 0.04 \\
Lactic acid, \%DM & $7.03^{\mathrm{b}}$ & $7.82^{\mathrm{b}}$ & $10.15^{\mathrm{ab}}$ & $10.99^{\mathrm{a}}$ & $6.11^{\mathrm{b}}$ & 0.16 \\
Acetic acid, \%DM & 2.00 & 1.98 & 2.13 & 2.48 & 2.20 & 0.04 \\
Lactic acid:acetic acid ratio & $3.51^{\mathrm{b}}$ & $3.15^{\mathrm{b}}$ & $4.76^{\mathrm{ab}}$ & $4.82^{\mathrm{a}}$ & $2.78^{\mathrm{b}}$ & 0.01 \\
Yeast/mold, log10 cfu/g & $5.03^{\mathrm{a}}$ & $4.72^{\mathrm{ab}}$ & $4.62^{\mathrm{b}}$ & $3.85^{\mathrm{b}}$ & $6.99^{\mathrm{a}}$ & 0.48 \\
LAB2, $\log 10 \mathrm{cfu} / \mathrm{g}$ & 9.45 & 10.02 & 10.48 & 10.26 & 9.1 & 0.52 \\
\hline
\end{tabular}

a,b, $\mathrm{P}<0.05 ; \mathrm{A}, \mathrm{B}, \mathrm{P}<0.01$

${ }^{1} \mathrm{U}$ - untreated maize silage; SD1 - silage treated with $0.05 \%$ sodium dehydroacetate; SD2 - silage treated with $0.1 \%$ sodium dehydroacetate; SD3 - silage treated with $0.2 \%$ sodium dehydroacetate; LM - silage treated with $0.35 \%$ LuproMix NC

${ }^{2} \mathrm{LAB}$ - lactic acid bacteria

Lactic acid bacteria count of each SD treated silage was numerically higher than that of U or PM. Of the three SD treatment, SD2 treatment had the highest $\mathrm{cfu} / \mathrm{g}$ of lactic acid bacteria (10.48). Regardless of SD application rates, treatments with SD did not affect the growth of lactic acid bacteria when compared with untreated silage. The effectiveness of SD as antifungal additive increased with SD application rate, and SD treatments had lower yeast/mold numbers relative to both controls. However, no differences in lactic acid bacteria numbers among all the treatment were detected.

No differences were detected in the concentrations of lactic acid among all of the treatments with the exception that SD3 significantly increased the concentration of lactic acid (10.99\%) compared with U or LM. In addition, the LM-treated silage had the lowest lactic acid content, and the difference attained significant level of $\mathrm{P}<0.10$ compared with $\mathrm{U}$. There were no differences in the concentration of acetic acid among all the treatments. Similarly, lactate:acetate ratio of all the treatments did not differ among all the treatment except for SD3 having the greatest ratio of lactate: acetate. Even though silage treated with LM had the lowest ratio of lactic acid:acetic acid of all treatments, the difference was not statistically significant compared with $\mathrm{U}$.

\section{DISCUSSION}

The results showed that addition of SD in blue-grass silage could lower $\mathrm{pH}$ and ammonia nitrogen level compared with $\mathrm{U}$. The ammonia- $\mathrm{N} /$ total $\mathrm{N}$ ratio is a good 
indicator of the silage quality. Low ammonia concentration of silage is associated with high silage quality, which means no extensive protein degradation. Due to addition of SD, the rate of $\mathrm{pH}$ drop increased, resulting in less nutrient losses.

The silage treated with LM did not contain as much lactic acid as did untreated silage. This result suggested that LM took over the role of the lactic acid bacteria to a certain extent and partially inhibited the natural fermentation of sugars to lactic acid by the lactic acid bacteria. LM-treated silage had predictablely the highest concentration of propionic acid $(0.91 \%)$, whereas propionic acid content of other treatments were much fewer or undetectable (data not shown). In fact, buffered propionic acid is the main active ingredient in LM but acetic acid is the major effective component of SD. As expected, they quickly reduced the $\mathrm{pH}$ so that mold and yeast were inhibited. Our finding is in agreement with previous studies with propionate-based antifungal additive (Kung et al., 1998, 2000).Unlike propionate, the SD did not affect both growth of lactic acid bacteria and the concentration of lactic acid, suggesting that this finding was caused by inhibition of yeasts and not lactic acid bacteria. During ensiling, SD is degraded into acetic acid, which is highly antifungal. In addition, this compound is a strong reducing agent that can consume large quantities of oxygen during ensiling; thereby reducing the time that the fresh forage is under aerobic stress. In other words, action mode of SD was different from LM. Our data support this contention because SD3 treatment had the greatest level of lactic acid and the highest ratio of lactate: acetate, indicating a more homolactic acid type of fermentation.

In the present experiment, when application rate of SD was less than $0.1 \%$ of fresh forage weight, treatment with SD was proved to be ineffective at improving fermentation of blue-grass silage. In agreement with our findings, the use of low dose of chemical additive in some studies failed to inhibit the growth of yeasts and to improve silage quality (Kung et al., 1998, 2000; Kleinschmit et al., 2005).

In general, SD played significant role in both encouraging lactic acid fermentation and inhibiting yeast/mould proliferation as summarized in Table 1. From viewpoint of nutrition, higher cost of per tonne SD-treated silage may be offset to some extent by lowering storage losses or improving nutritive value. Furthermore, the cost /tonne of silage treated with SD3 is 12 Yuan cheaper than that of LM. Consequently, the efficacy and cost of SD as a antifungal additive is acceptable.

\section{CONCLUSIONS}

Addition of sodium dehydroacetate (SD) to the blue-grass silage helped in the fermentation of the silage and inhibited aerobic bacteria growth and had the capacity to bind protein, preventing some protein breakdown to ammonia. To 
overcome drawbacks with some fermentation inhibitor that are expensive and not particularly pleasant or safe to handle, it is suggested that SD is a promising substitue as a antifungal additive.

\section{REFERENCES}

Buxton D.R., Muck R.E., Harrison J.H., 2003. Silage Science and Technology. American Society of Agronomy, Inc., Crop Science Society of America, Inc., Soil Science Society of America, Inc. Publications, Madison, WI

Hingston A.R., Christensen D.A., 1982. The effect of type of silo and formic acid preservation on the nutritive value of barley, wheat and oat silage for growing Hereford steers. Can. J. Anim. Sci. 62, 155-162

Hoffman P.C., Ocker S.M., 1997. Quantification of milk yield losses associated with feeding aerobically unstable high moisture corn. J. Dairy Sci. 80, Suppl. 1, 234 (Abstr.)

Kleinschmit D.H., Schmidt R.J., Kung Jr. L., 2005. The effects of various antifungal additives on the fermentation and aerobic stability of corn silage. J. Dairy Sci. 88, 2130-2139

Kung Jr. L., Robinson J.R., Ranjit N.K., Chen J.H., Golt C.M., Pesek J.D., 2000. Microbial populations, fermentation endproducts, and aerobic stability of corn silage treated with ammonia or a propionic acid-based preservative. J. Dairy Sci. 83, 1479-1486

Kung Jr. L., Sheperd A.C., Smagala A.M., Endres K.M., Bessett C.A., Ranjit N.K., Glancey J.L., 1998. The effect of preservatives based on propionic acid on the fermentation and aerobic stability of corn silage and a total mixed ration. J. Dairy Sci. 81, 1322-1330

Lingvall P., Lattemae P., 1999. Influence of hexamine and sodium nitrite in combination with sodium benzoate and sodium propionate on fermentation and hygienic quality of wilted and long cut grass silage. J. Sci. Food Agr. 79, 257-264

Plegge S.D., 1992. SDA improving aerobic stability of corn or half-dried silage. Feedstuffs 64 (58), 19-26

SAS, 1998. SAS User's Guide. Statistics, Version 7 Edition. SAS Institute Inc. Cary, NC

Whitlock L.A., Wistuba T.J., Seifers M.K., Pope R.V., Bolsen K.K., 2000. Effect of level of surfacespoiled silage on the nutritive value of corn silage diets. J. Dairy Sci. 83, Suppl. 1, 110 (Abstr.) 